\title{
THE INFLUENCE OF THE COMPLEX TRAINING METHOD ON MAXIMAL ISOMETRIC FORCE PRODUCTION OF JUNIOR BASKETBALL PLAYERS
}

\section{INFLUENCIA DEL MÉTODO COMPLEJO DE ENTRENAMIENTO EN LA MANIFESTACIÓN DE FUERZA ISOMÉTRICA MÁXIMA DE LOS BALONCESTISTAS JUVENILES}

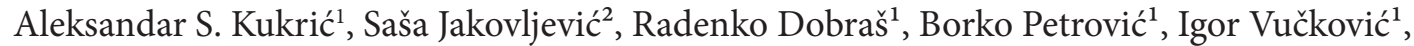 \\ Nenad Janković ${ }^{2}$ \\ ${ }^{1}$ Faculty of Physical Education and Sport, University of Banja Luka, Bosnia and Herzegovina \\ ${ }^{2}$ Faculty of Sport and Physical Education, University of Belgrade, Serbia
}

\begin{abstract}
During the period of ten weeks, a study has been conducted on the effects of a complex training method on the maximal isometric muscle force, its peaking time, and the rate of force development in the semi-squat test. The participants of the study were twenty junior basketball players (average age 16.4 $+/-0.7$; mean body height $186.2 \mathrm{~cm}+/-9.2$; mean body weight $75,4+/-7.5 \mathrm{~kg}$; mean body fat percentage $12,83 \%+/-1.15)$. The participants were divided into experimental $(n=10)$ and control group $(n=10)$. The experimental group, besides technical-tactical training sessions, had additional complex training, while the control group had technical-tactical training sessions only. At the final testing, the results of maximal isometric muscle force and the explosive power index, have significantly improved in the experimental group, while the control group did not make significant progress. There were no significant changes in the maximal isometric muscle force's peak time at the final testing. The study findings indicate that application of the complex training method has positive effects on the development of maximal isometric force, and the rate of force development.
\end{abstract}

Key words: EXPLOSIVE POWER / POSTACTIVATING POTENTIATION / REACTIVE TRAINING / JUNIOR BASKETBALL PLAYERS

\begin{abstract}
EXTRACTO
En el período de diez semanas se ha realizado una investigación de los efectos del método complejo de entrenamiento sobre la fuerza muscular isométrica máxima, el tiempo de su alcance y el índice de la fuerza explosiva en la prueba de flexión de piernas. En la investigación participaron los 20 baloncestistas de edad juvenil (edad promedia $16.4+/-0.7$ años; de altura corporal promedia $186.2 \mathrm{~cm}+/-9.2$; de masa corporal promedia $75,4+/-7.5 \mathrm{~kg}$; de valor promedio del porcentaje de tejido graso $12,83 \%+/-1.15)$. Los examinados se han dividido en el grupo experimental $(n=10)$ y en el grupo de control $(n=10)$. El grupo experimental, además de los entrenamientos técnico-tácticos de baloncesto, realizaba adicionalmente el programa de entrenamiento complejo, mientras que el grupo de control tenía solo los entrenamientos técnico-tácticos de baloncesto. En la medición final los resultados de la máxima fuerza muscular isométrica y del índice de la fuerza explosiva tenían estadísticamente una mejoría considerable en el grupo experimental, mientras que en el grupo de control no se han notado cambios importantes. En la medición final no se han notado unos cambios más importantes en el tiempo de alcanzar la fuerza isométrica máxima. Sobre la base de los resultados de la investigación se puede concluir que la aplicación del método complejo de entrenamiento tiene efectos positivos en el desarrollo de la fuerza muscular isométrica máxima, como también en el índice de la fuerza explosiva.
\end{abstract}

Palabras claves: FUERZA EXPLOSIVA / POTENCIACIÓN POST-ACTIVACIÓN / ENTRENAMIENTO RECREATIVO / BALONCESTISTAS JUVENILES 


\section{INTRODUCTION}

Complex training belongs to the group of reactive training methods, whose main role is to develop maximal muscle force through overcoming large and small loads in high speed movements (Siff, \& Verkhoshansky, 1999). Reactive training method is one of the methods with explosive dynamic efforts, alongside complex training method, and the plyometric method. The complex training has been founded by Russian scientists, and its mechanism of operation draws more attention during the 80s. National Strength and Conditioning Association - NSCA, in 1986 organized a visit of 40 coaches from the USA and Canada to the Institute of Sports in Moscow, where they for the first time saw a new training method that rest on the overcoming of large and small loads within a single set (Xenofondos et al., 2010). The method was based on the execution of several exercise sets with large loads and low movement speed, followed by a series of exercises with a relatively small load and high movement speed. The exercises ought to be performed in a biomechanically similar way, and to be anatomically congruent, hence to activate the same muscle groups in both exercises of one complex (i.e. squat and vertical jump). Apart from the complex method, other known methods include contrast and traditional method. Contrast training means alternating large and small loads within one set, while traditional training connotes alternating small and large loads within one set (Duthie, Young, \& Aitken, 2002).

At the heart of the complex training method is the physiological mechanism of post-activation potentiation (PAP). Robins (2005) defines PAP as a physiological phenomenon, which due to muscle activation, enables improvement of the following muscle activation. Muscle excitability resulting from acute physiological adaptation will lead to an improvement in the exertion of muscle force in subsequent muscle activation. The force gradient, which represents the rate of increase of force in a unit of time, will increase particularly. Studies have shown that after coping with large external loads, in the next period, for a few seconds, up to several minutes, significant effects of PAP can be induced, especially in activities such as jumping, sprinting, throwing (Robbins, 2005; Jensen, \& Ebben, 2003). Two physiological mechanisms are thought to be responsible for the existence of PAP. The first one is based on the phosphorylation of myosin regulatory light chains, which makes actin and myosin more sensitive to calcium, which is released from the sarcoplasmic reticulum during explosive muscle contraction (Robbins, 2005; Weber et al., 2008; Hodgson, Docherty, \& Zehr, 2008). The second mechanism is based on the existence of increased synaptic excitation within the spinal cord, leading to increased generation of muscle force (Wilson et al., 2013). In programming a complex training method, consideration should be given to reconciling two variables: the magnitude of the external load and the length of the break between the two exercises in the complex. The study has mainly examined the effect of training levels, types of muscle fibers, gender, varying intensity and volume of preload, as well as types of preload (dynamic or isometric), on different output parameters of the athlete's motor skills (jump, sprint, throw, force and power parameters) (Tsolakis et al., 2011; French, Kramer, \& Cooke, 2003; Requena et al., 2008; Rixon, Lamont, \& Bemben, 2007; Kukrić et al., 2009; Ebben, Jensen, \& Blackard, 2000; Roden, Lambson, \& DeBeliso, 2014).

Some studies have shown that trained athletes are more responsive to PAP than recreational athletes (Gourgoulis et al., 2003; Chiu, et al., 2003). The effects of PAP are more evident in fast muscle fibers compared to slow muscle fibers (Seitz, de Villarreal, \& Haff, 2014). Concerning gender, Jensen et al. (1999), concluded that there was no difference in the effects of PAP between men and women. Wilson et al. (2013), in a meta-analysis of PAP effects, concluded that the greatest effect is achieved by applying an external load in the range of $60-84 \%$ of $1 \mathrm{RM}$ and that the break between the two exercises in the complex is 7-10 minutes. Besides, it was concluded that there were no statistically significant differences between the application of dynamic and isometric preloads. More research recommends a break of 3 to 4 minutes between the two exercises in the complex because then the effects of PAP are most pronounced (Burger, Boyer-Kendrick, \& Dolny, 2000; Jensen et al., 1999; Ebben et al., 2000; Wilson et al., 2013).

The effects of PAP have generally been tested under conditions of dynamic movements (jump, sprint, throw). The purpose of this study is to investigate the effect of PAP on the isometric muscle force of leg extensions. Since these are young athletes, changes in isometric muscle force are expected at the end of the 
experiment. There are studies that have examined the effects of plyometric training, as a reactive training method, on isometric muscle force. Behrens et al. (2016), tested the effects of plyometric training on isometric, concentric and eccentric muscle contraction. The results showed that regardless of the mode of muscle work, plyometric training has positive effects on the exertion of muscle force. Another study confirmed that plyometric exercises, consisting of maximal vertical jumps and deep jumps from different heights, increase the maximal isometric force of the extensor muscle in the knee joint (Clutch et al., 2013).

On the other hand, it should be noted that there are also research that have not proven the effectiveness of PAP (Comyns, Harrison, \& Hennessy, 2010; Comyns et al., 2006; Ebben \& Blackard, 1997; Gossen \& Sale, 2000).

The aim of this study is to investigate the impact of a complex training method on maximal isometric muscle force, its peak time, and rate of force development. Using the special training program, the effects of dynamic training on the force-velocity curve under isometric stress conditions were tested.

\section{METHOD}

\section{Participants}

Twenty junior basketball players, with at least five years of playing experience, participated in the study (average age 16.4+/-0.7; mean body height $186.2 \mathrm{~cm}+/$ 9.2; mean body weight $75,4+/-7.5 \mathrm{~kg}$; mean body fat percentage $12,83 \%+/-1.15)$. Before the commencement of the experimental program, participants were divided into experimental and control group. There were 10 participants in each group. Based on the Zvalues, the groups were homogenized, which was one of the important methodological conditions for starting the experiment with parallel groups. The participants are of normal health status, free of injuries and orthopedic limitations that could affect the results of the study and are fully aware of the goals and objectives of the experiment and have voluntarily accepted to participate in the research.

\section{Variables}

The variables are divided into two groups. Independent variables related to the morphological characteristics of the participants: body weight (BW), body height $(\mathrm{BH})$ and body fat percentage (BFP). The dependent variables represented the maximum isometric muscle force in the semi-squat test (SST), the time of maximum isometric muscle force (MIF) and the rate of force development (RFD). The maximum isometric muscle force is expressed in newton $(\mathrm{N})$, the time to reach the maximum isometric muscle force is expressed in seconds (s), while the RFD is expressed in $\mathrm{N} / \mathrm{s}$.

\section{Procedure}

The plan and program of the experiment were presented to the participants in detail. At the first gathering, the morphological characteristics of the participants were measured, after which the maximum isometric muscle effort was measured with the semi-squat test. Since the muscle can develop maximum muscle force only at the appropriate joint angle, called the optimum joint angle, testing was performed at a $90^{\circ}$ angle at the knee joint. At this angle, due to the longest force arm, the total torque in the knee joint is the greatest. One study found that there was a high correlation $(r=0.77)$ between an isometric semi-squat at an angle of $90^{\circ}$ in the knee joint and one repetitive maximum in a semi-squat exercise performed in the dynamic muscle mode. Performing an isometric semi-squat at a knee joint angle of $90^{\circ}$ and $120^{\circ}$ will provide a strong effect on one repetitive maximum in the semi-squat exercise (Bazyler, Beckham, \& Sato, 2015).

The testing was performed on a semi-squat fitness machine. The testing protocol implied that the participants take the standard position of the body for performing the semi-squat, with a goniometer determining the angle of $90^{\circ}$ in the knee joint. This fulfills the biomechanical prerequisites for proper semi-squat. The testing of isometric effort took at least 3 seconds from the beginning of the development of muscle force. The participants were required to perform the contraction as fast as they could. The next day, following the recommendations of Brzycki (1993), participants performed the semi-squat test with one repetitive maximum (1RM). 
Based on all of the measurements, the participants were divided into two homogeneous groups. The experiment was organized over 10 weeks, in which the participants of the experimental group, in addition to regular basketball training, had twice a week sessions with a complex training model. The training program consisted of 3 to 5 exercises aimed at the development of the lower extremities. The exercise complex consisted of the back semi-squat exercise, with a high external load ( $80 \%$ of $1 \mathrm{RM}$ ) in 4 sets, with 4 to 6 reps, with a break between sets of 3 minutes. This would be followed by a 2-minute break and after that a set of vertical jump exercises in 4 sets, with 10 reps each, with a 3-minute break between sets. In addition to this set of exercises, other exercises were used that are anatomically and biomechanically very similar to the example above (e.g. semi-squat on one leg and jump with one leg; front squat and long jump...). Young et al. (1998) recommended a very similar training program, with a break between two exercises in the complex for 2 minutes. The control group, except for regular basketball training, had no additional work. After 10 weeks, the final measurement of the variables was done in the same way as the initial measurement.

All measurements were performed under laboratory conditions. Body height was measured with a Seca (Germany) stadiometer, while body weight and body fat percentage were measured by a specialized instrument for body composition measurement
Tanita bc-418ma (Japan). Using the Globus Ergo Tesys System 1000, Real power (Italy) dynamometer, the maximum isometric muscle force and the time at which it was reached in the semi-squat test were measured with dynamometric method.

\section{Statistical data processing}

Using the appropriate operational statistical program (SPSS), the arithmetic mean and standard deviation were calculated for all variables. Post hoc analysis (Tukey's HSD criterion) was used to determine whether the groups differ from each other in the initial measurement. By applying the t-test for dependent samples, the difference of the results at the initial and final measurements for each group was tested. The significance level was set at $\mathrm{p}=0.05$.

\section{RESULTS}

Table 1. shows the mean and standard deviations of the morphological characteristics of junior basketball players. The values of body height, body weight and body fat percentage are approximately equal in the experimental and control groups at the initial and final measurements.

Table 1. Descriptive statistical indicators of morphological characteristics of the sample at initial and final measurement

\begin{tabular}{lcccc}
\hline \multicolumn{5}{c}{ Initial measurement } \\
\hline Variable & \multicolumn{2}{c}{ Experimental group } & Control group \\
\hline Mean & SD & Mean & SD \\
BH (cm) & 186.00 & 4.34 & 186.40 & 4.19 \\
BW (kg) & 75.00 & 4.57 & 75.80 & 3.08 \\
BFP (\%) & 12.81 & 1.43 & 12.86 & 0.91 \\
& & Final measurement & & \\
\hline Variable & Experimental group & Control group & SD \\
\hline & Mean & SD & Mean & 4.21 \\
BH (cm) & 186.40 & 4.22 & 186.80 & 2.71 \\
BW (kg) & 75.30 & 4.78 & 76.15 & 0.74 \\
BFP (\%) & 12.56 & 1.23 & 12.81 & \\
\hline
\end{tabular}

Table 2. shows the mean values and standard deviations of the maximum isometric muscle force, its peak time, and the rate of force development in the semi-squat test at the initial and final measurement. 
Kukrić A., et al, The Influence of the Complex Training Method ..., PHYSICAL CULTURE 2019; 73 (2): 261-270

Table 2. Statistical indicators of maximal isometric muscle force, its peak time, and the rate of force development in the semi-squat test at the initial and final measurement.

\begin{tabular}{lcccccccc}
\hline & \multicolumn{3}{c}{ Initial measurement } & \multicolumn{4}{c}{ Final measurement } \\
\hline Variable & \multicolumn{2}{c}{ Exper. group } & \multicolumn{2}{c}{ Cont. group } & \multicolumn{2}{c}{ Exper. group } & \multicolumn{2}{c}{ Cont. group } \\
\cline { 2 - 9 } & Mean & SD & Mean & SD & Mean & SD & Mean & SD \\
\cline { 2 - 9 } SST (N) & 1442.21 & 198.49 & 1441.01 & 149.31 & 1647.32 & 174.06 & 1461.51 & 145.97 \\
MIF (s) & 1.47 & 0.25 & 1.45 & 0.16 & 1.43 & 0.22 & 1.44 & 0.16 \\
RFD (N/s) & 981.09 & 220.41 & 993.80 & 162.40 & 1151.97 & 185.47 & 1014.93 & 155.31 \\
\hline
\end{tabular}

Table 3. shows the results of the analysis of variance at the initial measurement. There were no statistically significant differences observed in the tested variables between the experimental and control groups at the initial measurement. This satisfied one of the basic methodological requirements of research with parallel groups, where is necessary that at the beginning of the experiment, there is no statistically significant difference in the tested variables between the groups.

Table 3. Results of the analysis of variance of the experimental and control groups at the initial measurement

\begin{tabular}{lcc}
\hline Variable & F-test & Control group \\
\hline SST (N) & .39 & .68 \\
MIF (s) & .11 & .89 \\
RFD (N/s) & .99 & .38 \\
\hline
\end{tabular}

Table 4. shows the results of the t-test for dependent samples. The significance of differences between the means of the experimental and control group vari- ables at the initial and final measurements was tested. Measurement results indicate that there is no statistically significant difference in the experimental group in the SST and RFD variables, whereas no statistically significant differences were observed in the MIF variable. No significant differences were observed in the control group in any of the tested variables.

Table 4. Significance of differences between variable means of the experimental and control group at the initial and final measurements

\begin{tabular}{lcccc}
\hline Variable & \multicolumn{2}{c}{ Experimental group } & \multicolumn{2}{c}{ Control group } \\
\hline & t-test & Sig. & t-test & Sig. \\
\hline SST (N) & $-16.59^{\star}$ & $.00^{\star}$ & -1.76 & .11 \\
MIF (s) & 1.33 & .21 & .10 & .91 \\
RFD (N/s) & -6.89 & .00 & -.59 & .56 \\
\hline
\end{tabular}

* Statistically significant difference

Figures 1, 2 and 3 show the significance of differences in the arithmetic means of the tested variables of the experimental and control group participants at the initial and final measurements in the semi-squat test.

Final measurement

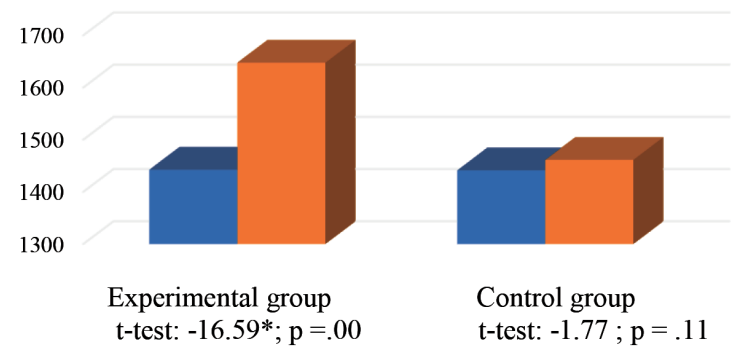

Figure 1. Significance of differences in the arithmetic means of the maximal isometric muscle force $(\mathrm{N})$ of the experimental and control group participants at the initial and final measurements 
Initial measurement Final measurement

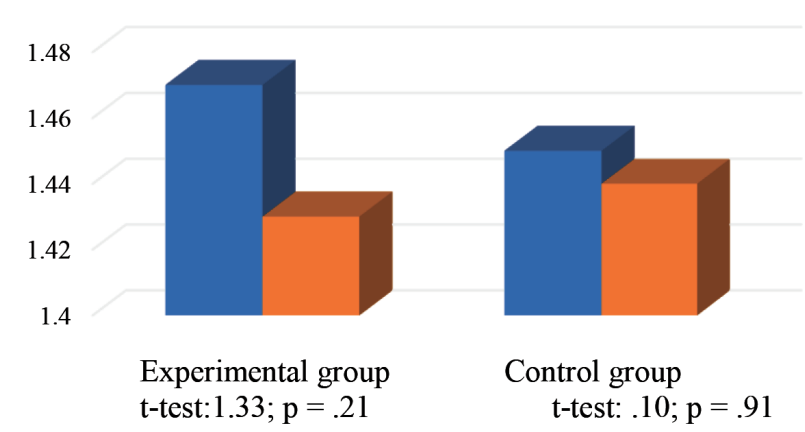

Figure 2. Significance of mean differences in the peak time of the maximum isometric muscle force (s) of the experimental and control group participants at the initial and final measurements

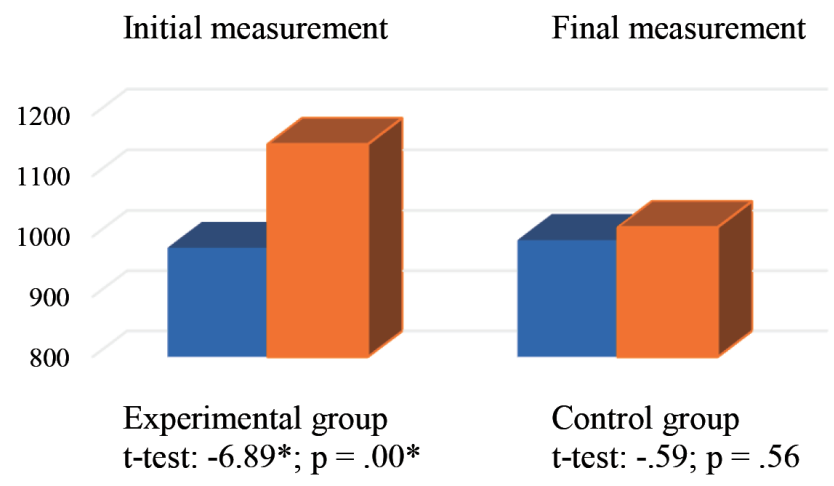

Figure 3. Significance of differences in arithmetic means the rate of force development (N/s) of experimental and control group participants at the initial and final measurements.

\section{DISCUSSION}

The values of the measured morphological characteristics indicate that the participants are of the appropriate ratio of body height and body mass, with a relatively small proportion of fat tissue in the body composition (Table 1.). There were no significant changes in the participants' morphological attributes observed on the final measurement. The whole exercise program made no significant effects on body weight and the body fat percentage. Concerning body height, no significant changes were expected during the short period of the experimental program. Considering the impact of a complex training method, based on the performance of explosive and rapid movements, it is quite clear why there was no activation of metabolic processes, which would significantly affect the percentage of fat tissue and body weight.
The measured values of maximal isometric muscle force, its peak time, and the rate of force development at the initial measurement indicate that the participants have approximately similar abilities in producing isometric effort in the semi-squat test (Table 2). The results of the analysis of variance at the initial measurement indicate the absence of significant differences between the sample groups, which allowed the commencement of the experimental program (Table 3).

The results of the final measurement of isometric effort in the semi-squat test indicate that, after a tenweek exercise program, certain changes occurred in the production of maximal isometric muscle force (Table 4, Figures 1, 2 and 3). On the final measurement, statistically significant differences were found in the SST and RFD variables in the experimental group. Monitoring the parameter changes in the semi-squat test revealed an increase in the maxi- 
mum isometric force by $14.22 \%$, as well as improving the rate of force development by $17.41 \%$ over initial measurement. Although no significant changes in the peak time of reaching maximal isometric muscle force occurred, the improvement in the rate of force development was the result of a significant increase in maximal isometric muscle force. No significant changes in the tested variables were registered in the control group.

The absence of significant changes in the control group variables was fully expected since the participants did not undergo the training program for the development of force and strength; therefore no significant changes could be expected on the forcevelocity curve. As no significant changes occurred in the control group, any resulting improvements in the experimental group, with a high level of probability, could be attributed to the implementation of the experimental ten-week exercise program.

Significantly higher values of maximal isometric muscle force in the semi-squat test indicate that dynamic exercises have a positive effect on isometric effort. Although a change in the rate of muscular contraction was also expected, since the exercise program involved the execution of explosive movements in eccentric-concentric contraction mode, this change did not occur this time. Some studies have confirmed that resistance training can affect the speed of muscle force development in isometric conditions. One of the studies concluded that resistance training can increase the frequency of nerve impulse discharges and that this increase may cause a greater rate of muscle force development (Sale, 2003). As one of the possible reasons why there was no change in the time of manifestation of maximal isometric muscle force, the relatively short break between potentiation and explosive exercise can be considered.

As it is known, the effects of performing highspeed explosive exercises are greatest under conditions of complete muscle recovery. It may be possible that the two-minute break was not sufficient for a full recovery, especially for the recovery of the neural component of muscle activity, which largely depends on the speed of exertion of muscle force. Seitz et al. (2014) concluded in their study that the most pronounced effects of PAP were observed in trained athletes after a 6-minute break between exercises in the complex, while in less-trained athletes breaks were as long as 9 minutes. As only significant changes in isometric force were observed, it can be concluded that the effects of complex training are primarily directed to muscle adaptation and that the changes probably occurred as a result of alterations in physiological muscle cross-section.

There are two components that determine the exertion of maximum muscle force. The neural component refers to the activity of the central nervous system (CNS), which in many ways affects muscle activity. From the aspect of CNS influence, a maximal muscular force can be developed by recruiting as many motor units as possible, optimal frequency of nerve impulse discharge in order to create tetanus contraction and simultaneous action of motor units in a short period during maximal voluntary contraction (Sale, 2003). Muscle component refers to the influence of muscle structure and architecture on the maximum muscle force. Maximum muscle force may increase at the expense of an increase in physiological muscle cross-section (Luthi et al., 1986; Young, Stokes, \& Round, 1983; Folland, \& Wiliams, 2007; Fitts, \& Widrick, 1996), which may result from two physiological mechanisms, hypertrophy, and hyperplasia.

The greatest changes in muscular architecture result from hypertrophy rather than hyperplasia. Häkkukinen, Komi, \& Alén (1985) examined the influence of explosive strength training on the isometric force of the leg extensor muscle over 24 weeks. They applied electromyographic measurement and analyzed the force-velocity curve and found a statistically significant improvement in the maximal isometric force of the leg extensor muscles, as well as an improvement in the rate of isometric muscle force generation. As one of the causes of these improvements, the authors cite an increase in muscle physiological cross-section, especially in the conditions of performing plyometric exercises in combination with additional external loading. Similar results were found in a 12-week study where muscle changes were followed by biopsy in the cross-section of $\mathrm{m}$. bicep brachii. An increase was found in the cross-section of fast twitch fibers by $17 \%$ and slow twitch fibers by 10\% (McCall et al., 1996). 


\section{CONCLUSION}

In recent decades, the effects of complex training, which is a reliable method in the preparation of athletes, have been increasingly explored and many coaches recommend it as an effective method in training process. The special significance of this research is reflected in the examination of the effects of complex training on the parameters of force and time at isometric muscle effort. The results of the study confirmed the effectiveness of a complex training

\section{REFERENCE}

1. Bazyler, C.D., Beckham, G.K., Sato, K. (2015). The Use of the Isometric Squat as a Measure of Strength and Explosiveness. Journal of Strength \& Conditioning Research, 29(5), 1386-1392.

2. Behrens, M., Mau Moeller, A., Mueller, K., Sandra Heise, S., Gube, M., Beuster, N., Herlyn, P.K.E., Fischer, D.C., \& Bruhn, S. (2016). Plyometric training improves voluntary activation and strength during isometric, concentric and eccentric contractions. Journal of Science and Medicine in Sport, 19(2), 170-176.

3. Brzycki, M. (1993). Strength testing: Predicting a one-rep max from reps to fatigue. Journal of Physical Education, Recreation and Dance, 64, 88-90.

4. Burger, T., Boyer-Kendrick, T., \& Dolny, D. (2000). Complex training compared to a combined weight training and plyometric training program. Journal of Strength \& Conditioning Research, 14(3), 360-361

5. Chiu, L. Z., Fry, A. C., Weiss, L. W., Schilling, B. K., Brown, L. E., \& Smith, S. L. (2003). Postactivation Potentiation Response in Athletic and Recreationally Trained Individuals. Journal of Strength and Conditioning Research, 17(4), 671-677.

6. Clutch, D., Wilton, M., McGown, C., \& Bryce, G.R. (2013). The Effect of Depth Jumps and Weight Training on Leg Strength and Vertical Jump. Research Quarterly for Exercise and Sport, 54(1), 5-10.

7. Comyns, T.M., Harrison, A.J., \& Hennessy, L.K. (2010). Effect of squatting on sprinting performance and repeated exposure to complex train- method to exert maximum isometric muscle force. Statistically significant improvements in results were obtained in the group that trained with the complex method of training compared to the control group. The application of the experimental program did not lead to significant changes in the time of maximum isometric force. It is evident that under the influence of the experimental program only adaptations of muscle tissue to force and strength training occurred, which led to significant improvements in the production of maximal muscle force in conditions of isometric effort. ing in male rugby players. Journal of Strength \& Conditioning Research, 24, 610-618.

8. Comyns, T.M., Harrison, A.J., Hennessy, L.K., \& Jensen, R.L. (2006). The optimal complex training rest interval for athletes from anaerobic sports. Journal of Strength \& Conditioning Research, 20, 471-476.

9. Duthie, G. M., Young, W. B., \& Aitken, D. A. (2002). The acute effects of heavy loads on jump squat performance an evaluation of the complex and contrast methods of power development. Journal of Strength and Conditioning Research, 16(4), 530-538.

10. Ebben, W.P., \& Blackard, D.O. (1997). Complex training with combined explosive weight training and plyometric exercises. Olympic Coach, 7, 11-12.

11. Ebben, W.P., Jensen, R.L., Blackard, D.O. (2000). EMG and kinetic analysis of complex training exercise variables. Journal of Strength \& Conditioning Research, 14: 451-456.

12. Fitts, R.H., \& Widrick, J.J. (1996). Muscle mechanics: adaptations with exercise-training. Exercise and Sport Sciences Reviews, 24, 427-473.

13. Folland, J.P., \& Williams, A.G. (2007). The adaptations to strength training: morphological and neurological contributions to increased strength. Sports Medicine, 37(2), 145-68.

14. French, D., Kramer, W.J., Cooke, C.B. (2003). Changes in Dynamic Exercise Performance Following a Sequence of Preconditioning Isometric Muscle Actions. Journal of Strength \& Conditioning Research, 17(4), 678-685. 
Kukrić A., et al, The Influence of the Complex Training Method ..., PHYSICAL CULTURE 2019; 73 (2): 261-270

15. Gossen, E.R., \& Sale, D.G. (2000). Effect of postactivation potentiation on dynamic knee extension performance. European Journal of Applied Physiology, 83(6), 524-530.

16. Gourgoulis, V., Aggeloussis, N., Kasimatis, P., Mavromatis, G., \& Garas, A. (2003). Effect of a submaximal half-squats warm-up program on vertical jumping ability. Journal of Strength and Conditioning Research, 17(2) 342-344.

17. Häkkukinen, K., Komi, P.V. \& Alén, M. (1985). Effect of explosive type strength training on isometric force and relaxation time, electromyographic and muscle fibre characteristics of leg extensor muscles. Acta Physiologica Scandinavica, $125,587-600$.

18. Hodgson, M.J., Docherty, D., Zehr E.Z. (2008). Postactivation Potentiation of Force Is Independent of H-Reflex Excitability. International Journal of Sports Physiology and Performance, 3(2), 219-231.

19. Jensen, R.L., \& Ebben, W.P. (2003). Kinetic analysis of complex training rest interval effect on vertical jump performance. Journal of Strength o Conditioning Research, 17(2), 345-9.

20. Jensen, R.L., Ebben, W.P., Blackard, D.O., Mclaughlin, B.P., \& Watts, P.B. (1999). Kinetic and electromyographic analysis of combined strength and plyometric training in women basketball players. Medicine \& Science in Sport \& Exercise, 31(5), 193.

21. Kukrić, A., Karalejić, M., Petrović, B., Jakovljević, S. (2009). Effect of complex training on explosive strength of legs extensors in junior basketball players. Physical Culture, 63(2), 165-180.

22. Luthi, J.M., Howald, H., Cbsen, H., Rosler, K., \& Vodc, P.H. (1986). Structural changes in skeletal muscle tissue with heavy resistance exercise. International Journal of Sports \& Medicine, 7(3), 123-127.

23. McCall, G. E., Byrnes, W. C., Dickinson, A., Pattany, P. M., \& Fleck, S. J. (1996). Muscle fiber hypertrophy, hyperplasia, and capillary density in college men after resistance training. Journal of Applied Physiology, 81(5), 2004-2012.

24. Requena, B., Gapeyeva, H., García, I., Ereline, J., Paasuke, M. (2008). Twitch potentiation after voluntary versus electrically induced isometric con- tractions in human knee extensor muscles. Euro Journal of Applied Physiology, 104(3), 463-472.

25. Rixon, K.P., Lamont, H.S., Bemben, M.G. (2007). Influence of type of muscle contraction, gender, and lifting experience on postactivation potentiation performance. Journal of Strength \& Conditioning Research, 21(2), 500-505.

26. Robbins, D.W. (2005). Postactivation potentiation and its practical applicability: a brief review. Journal of Strength \& Conditioning Research, 19(2), 453-458.

27. Roden, D., Lambson, R., DeBeliso, M. (2014). The Effects of a Complex Training Protocol on Vertical Jump Performance in Male High School Basketball Players. Journal of Sports Science, 2, 21-26.

28. Sale, D. G. (2003). Neural adaptations to strength training. In: Komi PV, editor. Strength and Power in Sport. 2nd ed. Malden (MA), Blackwell Science, 281-314.

29. Seitz, L.B., de Villarreal, E.S., \& Haff, G.G. (2014). The temporal profile of postactivation potentiation is related to strength level. Journal of Strength \& Conditioning Research, 28(3), 706-715.

30. Siff, M. C. \& Verkhoshansky, Y. V. (1999). Supertraining. Denver: Supertraining International.

31. Tsolakis, C., Bogdanis, G., Nikolaou, A., Zacharogiannis, E. (2011). Influence of type on muscle contraction and gender on postactivation potentiation of upper and lower explosive performance in elite fencers. Journal of Sports Science and Medicine, 10, 577-583.

32. Weber, K.R., Brown, L.E., Coburn, J.W., \& Zinder, S.M. (2008). Acute effects of heavy load squats on consecutive squat jump performance. Journal of Strength \& Conditioning Research, 22(3), 726-30.

33. Wilson, J.M., Duncan, N.M., Marin, P.J., Brown, L.E., Loenneke, J.P., Wilson, S.M., Jo, E., Lowery, R.P., \& Ugrinowitsch, C. (2013). Meta-analysis of postactivation potentiation and power: effects of conditioning activity, volume, gender, rest periods, and training status. Journal of Strength \& Conditioning Research, 27(3), 854-9.

34. Xenofondos, A., Laparidis, K., Kyranoudis, A., Galazoulas, Ch., Bassa, E., \& Kotzamanidis, C. (2010). Postactivation potentiation: factors affecting it and the effect on performance. Journal of Physical Education and Sport, 28(3), 32-38. 
Kukrić A., et al, The Influence of the Complex Training Method ..., PHYSICAL CULTURE 2019; 73 (2): 261-270

35. Young, A., Stokes, M., \& Round, J.M. (1983). The effect of high ristance training on the strength and cross sectional area of the human quadriceps. European Journal of Clinical Investigation, 13(5), 411-417.
36. Young, W. B., Jenner, A., \& Griffiths, K. (1998). Acute enhancement of power performance from heavy load squats. Journal of Strength \& Conditioning Research, 12(2), 82-84.

Submitted: 06.9.2018.

Accepted: 14.1. 2019.

Published Online First: 13.4.2019. 


\title{
УТИЦАЈ КОМПЛЕКСНОГ МЕТОДА ТРЕНИНГА НА ИСПОЉАВАЊЕ МАКСИМАЛНЕ ИЗОМЕТРИЈСКЕ СИЛЕ МЛАДИХ КОШАРКАША
}

\author{
Александар С. Кукрић ${ }^{1}$, Саша Јаковљевић ${ }^{2}$, Раденко Добраш ${ }^{1}$, Игор Вучковић ${ }^{1}$, Ненад Јанковић ${ }^{2}$ \\ ${ }^{1}$ Факултет физичког васпитања и спорта, Универзитет у Бањој Луци, Босна и Херцеговина \\ ${ }^{2}$ Факултет спорта и физичког васпитања, Универзитет у Београду, Србија
}

\begin{abstract}
Сажетак
У периоду од десет недеља, спроведено је истраживање ефеката комплексног метода тренинга на максималну изометријску мишићну силу, време њеног достизања и индекс експлозивне снаге у тесту получучањ. У истраживању је учествовало двадесет кошаркаша јуниорског узраста (просечне старости 16.4+/-0.7 год.; просечне телесне висине $186.2 \mathrm{~cm}+/-9.2$; просечне телесне масе $75,4+/-7.5 \mathrm{~kg}$; просечне вредности процента масног ткива 12,83\%+/-1.15). Испитаници су подељени у експерименталну (н=10) и контролну $(\mathrm{H}=10)$ групу. Експериментална група, поред техничко-тактичких кошаркашких тренинга, додатно је спроводила програм комплексног тренинга, док је контролна група имала само техничко-тактичке кошаркашке тренинге. На финалном мерењу, резултати максималне изометријске мишићне силе и индекса експлозивне снаге су се статистички значајно побољшали у експерименталној групи, док у контролној групи нису забележене значајније промене. Нису забележене значајније промене времена достизања максималне изометријске силе на финалном мерењу. На основу резултата истраживања, може се закључити да примена комплексног метода тренинга има позитивне ефекте на развој максималне изометријске мишићне силе, као и на индекс експлозивне снаге.
\end{abstract}

КљУчНе речИ: ЕКСПЛОЗИВНА СНАГА / ПОСТАКТИВАЦИЈСКА ПОТЕНЦИЈАЦИЈА / РЕАКТИВНИТРЕНИНГ / КОШАРКАШИ ЈуНИОРИ

\section{УВОД}

Комплексни тренинг спада у групу реактивних метода тренинга, чија је основна улога да савладавањем великих и малих оптерећења, у условима велике брзине покрета, развија максималну мишићну снагу (Siff, \& Verkhoshansky, 1999). Реактивни метод тренинга је један од метода експлозивних динамичких напрезања, у коме се поред комплексног тренинга налази још и плиометријски метод тренинга. Комплексни тренинг утемељен је од стране руских научника, а о његовом механизму деловања почело се тек говорити осамдесетих година прошлог века. У организацији National Strenght and Conditioning Association - NSCA, 1986. године, четрдесет тренера из Сједињених Америчких Држава и Канаде, посетили су Институт за спорт у Москви, где су се први пут сусрели са једном новом методом у тренажном процесу, у чијој основи лежи савладавање великог и малог оптерећења у оквиру једне серије извођења (Xenofondos et al., 2010). Метод се заснива на извођењу неколико серија вежби у којима се савладава велико оптерећење, са малом брзином извођења покрета, након чега би уследила серија вежби у коме се савладава релативно мало спољашње оптерећење, у условима велике брзине покрета. Вежбе би требало да се биомеханички изводе на сличан начин, да се анатомски подударају, односно, требало би да активирају исте мишићне групе у обе вежбе једног комплекса (нпр. задњи получучањ и вертикални скок из места). У пракси су поред комплексног, познате и друге методе, као што су, 
контрасни и традиционални метод. Контрасни тренинг подразумева наизменично савладавање великог, па малог оптерећења у оквиру једне серије, док традиционални тренинг подразумева савладавање малог, па великог оптерећења, у оквиру једне серије (Duthie, Young, \& Aitken, 2002).

У основи комплексног метода тренинга налази се физиолошки механизам постактивацијског потенцијација (ПАП). Робинс (Robins, 2005) дефинише ПАП као физиолошки феномен, који ће услед мишићне активације обезбедити да наредна контракција мишића буде значајно побољшана. Мишићна раздражљивост, настала услед акутне физиолошке адаптације, довешће до побољшања испољавања мишићне силе у наредној мишићној активацији. Посебно ће се повећати градијент силе, који представља брзину прираштаја силе у јединици времена. Истраживања су показала да након савладавања великих спољашњих оптерећења, у наредном периоду, у трајању од неколико секунди, па до неколико минута, могу се изазвати значајни ефекти ПАП, посебно у активностима какве су скок, спринт, бацања (Robbins, 2005; Jensen, \& Ebben, 2003). Сматра се да су два физолошка механизма одговорна за постојање ПАП. Први се заснива на фосфорилацији регулаторних лаких ланаца миозина, што актин и миозин чини осетљивијим на калцијум, који се ослобађа из саркоплазматичног ретикулума током експлозивне контракције мишића (Robbins, 2005; Weber et al, 2008; Hodgson, Docherty, \& Zehr, 2008). Други механизам се заснива на постојању повећане синаптичке ексцитације унутар кичмене мождине, што доводи до повећаног генерисања мишићне силе (Wilson et al., 2013).

У програмирању комплексног метода тренинга треба обратити пажњу на усаглашавање две варијабле: величину спољашњег оптерећења и дужину паузе између две вежбе у комплексу.

Истраживања су углавном испитивала утицај нивоа тренираности, врсте мишићних влакана, пола, различитог интензитета и волумена предоптерећења, као и врсте предоптерећења (динамичко или изометријско), на различите излазне параметре моторике спортисте (скок, спринт, бацање, параметре силе и снаге) (Tsolakis et al, 2011; French, Kramer, \& Cooke, 2003; Requena et al, 2008; Rixon, Lamont, \& Bemben, 2007; Кукрић и сар. 2009; Ebben, Jensen, \& Blackard, 2000; Roden, Lambson, \& DeBeliso, 2014).

Поједина истраживања су показала да трени= рани спортисти имају већу реакцију на ПАП, у односу на рекреативце (Gourgoulis et al, 2003; Chiu, et al., 2003). Ефекати ПАП су израженији код брзих мишићних влакана у односу на спора мишићна влакна (Seitz, de Villarreal, \& Haff, 2014). Што се тиче пола, Јенсен (Jensen et al, 1999) je закључио да не постоји разлика у ефектима ПАП између мушкараца и жена. Вилсон и сар. (Wilson et al, 2013) су у мета-анализи ефеката ПАП закључили да се највећи ефекат постиже применом спољашњег оптерећења у распону од $60-84 \%$ од $1 \mathrm{PM}$, а да пауза између две вежбе у комплексу буде 7-10 минута. Поред тога, закључено је да нема стистистички значајних разлика између примене динамичких и изометријских предоптерећења. Већи број истраживања препоручује паузу од 3 до 4 минута између две вежбе у комплексу, јер су тада ефекти ПАП најизраженији (Burger, Boyer-Kendrick, \& Dolny, 2000; Jensen et al, 1999; Ebben et al., 2000; Wilson et al., 2013).

Ефекти ПАП углавном су тестирани у условима извођења динамичких покрета кретања (скок, спринт, бацање). Намера овог истраживања је да се испита утицај ПАП на изометријску мишићну силу опружача ногу. Будући да се ради о младим спортистима, на крају експеримента се очекују промене у изометријској мишићној сили. Постоје истраживања која су испитивала ефекте плиометријског тренинга, као реактивне методе тренинга, на изометријску мишићну силу. Бехренс (Behrens, et al., 2016) је тестирао ефекте плиометријског тренинга на изометријску, концентричну и ексцентричну мишићну контракцију. Резултати су показали да без обзира на режим мишићног рада, плиометријски тренинг има позитивне ефекте на испољавање мишићне силе. Још једно истраживање је потврдило да плиометријске вежбе, које су се састојале од максималних вертикалних скокова и скокова у дубину са различите висине, утичу на повећање максималне изометријске силе мишића екстензора у зглобу колена (Clutch et al, 2013).

Са друге стране, треба истаћи да постоје и истраживања која нису доказала ефикасност ПАП (Comyns, Harrison, \& Hennessy, 2010; Comyns et al, 2006, Ebben \& Blackard, 1997, Gossen \& Sale, 2000). 
Кукрић А., и сар., Утицај комплексног метода тренинга..., ФИЗИЧКА КУЛТУРА 2019; 73 (2): 261-270

Циљ овог истраживања је да испита утицај комплексног метода тренинга на максималну изиметријску мишићну силу, време њеног достизања и индекс експлозивне снаге. Применом посебног тренажног програма, тестирани су ефекти динамичког тренинга на криву силабрзина у условима изометријског напрезања.

\section{МЕТОД РАДА}

\section{Узорак испитаника}

У истраживању је учествовало двадесет кошаркаша јуниорског узраста (просечне старости 16.4+/-0.7 год.; просечне телесне висине $186.2 \mathrm{~cm}+/-9.2$; просечне телесне масе 75,4+/-7.5kg; просечне вредности процента масног ткива $12,83 \%+/-1.15)$, са најмање пет година искуства бављења кошарком. Пре почетка експерименталног програма, испитаници су подељени у експерименталну и контролну групу. У свакој од група налазило се 10 испитаника. На основу Z-вредности групе су хомогенизоване, што је био један од важних методолошких услова за почетак експеримента са паралелним групама. Ипитаници су нормалног здравственог статуca, без повреда и ортопедских орграничења која би могла утицати на резултате истраживања и у потпуности су упознати са циљевима и задацима експеримента, те су својевољно прихватили да учествују у истраживању.

\section{Узорак варијабли}

Варијабле су подељене у две групе. Независне варијабле су се односиле на морфолошке карактеристике испитаника: телесна маса (ТМ), телесна висина (ТВ) и проценат масног ткива (MT). Зависне варијабле представљале су максималну изометријску мишићну силу у тесту получучањ (МИС), време остварења максималне изометријске мишићне силе (ВМИС) и индекс експлозивне снаге (ИЕС) (eng - Race of force development - RFD). Максимална изометријска мишићна сила изражава се у њутнима (N), време достизања максималне изометријске мишићне силе изражава се у секундама (s), док се ИЕС изражава у $\mathrm{N} / \mathrm{s}$.

\section{Ток и поступци истраживања}

Испитаницима је детаљно представљен план и програм експеримента. На првом окупљању измерене су морфолошке карактеристике испитаника, након чега је мерено максимално изометријско напрезање мишића у тесту получучањ. Будући да мишић може да развије максималнумишићнусилусамоприодговарајућем зглобном углу, који се назива оптимални зглобни угао, тестирање је вршено при углу од $90^{\circ}$ у зглобу колена. При том углу, захваљујући најдужем краку силе, укупни момент силе у зглобу колена је највећи. У једном од истраживања установљено je да постоји висока корелација $(\mathrm{r}=0,77)$ између изометријског получучња при углу од $90^{\circ}$ у зглобу колена и једног репетитивног максимума у вежби получучањ, изведеним у динамичком режиму рада мишића. Извођење изометријског получучња при углу у зглобу колена од $90^{\circ}$ и $120^{\circ}$, обезбедиће снажан утицај на један репетитивни максимум у вежби получучањ (Bazyler, Beckham, \& Sato, 2015).

Мерење је вршено на фитнес машини за получучањ. Протокол мерења је подразумевао да испитаници заузиму стандардну позицију тела за извођење получучња, при чему је за сваког испитаника гониометром утврђен угао од $90^{\circ}$ у зглобу колена. Тиме су задовољени биомеханички предуслови за извођење правилног получучња. Мерење изометријског напрезања трајало је најмање 3 секунде од почетка развоја мишићне силе. Од испитаника се захтевало да контракцију изведу најбрже што могу. Следећи дан, по препорукама Брзицког (Brzycki, 1993.), испитаницима је урађена процена једног репететативног максимумума (1PM) у тесту получучањ.

На основу свих мерења, испитаници су подељени у две хомогене групе. Експеримент је организован у периоду од 10 седмица, у коме су испитаници експерименталне групе, поред редовних кошаркашких тренинга, тренирали два пута недељно комплексним моделом тренинга. Програм тренинга састојао се од примене 3 до 5 вежби, усмерених на развој доњих екстремитета. Комплекс вежби се састојао од вежбе задњи получучањ, при чему се савладавало велико спољашње оптерећење ( $80 \%$ од $1 \mathrm{PM}$ ) у 4 серије, са по 4 до 6 понављања, док је пауза између серија била 3 минута. Након тога уследила би пауза од 2 
минута, а потом би се изводила вежба вертикалног скока у месту, у 4 серије, са по 10 понављања, док је пауза између серија износила 3 минута. Поред овог комплекса вежби, користиле су се и друге вежбе, које су анатомски и биомеханички врло сличне претходно наведеном примеру (нпр. получучањ на једној нози и скок са једне ноге; предњи чучањ и скок у даљ...). Јанг и сарадници (Young, Jenner, \& Griffiths, 1998) препоручују врло сличан програм тренинга, при чему је пауза између две вежбе у комплексу 2 минута. Контролна група, осим редовних кошаркашких тренинга, није имала додатни рад. Након десетонедељног периода, урађено је финално мерење варијабли, на идентичан начин као што је то рађено на иницијалном мерењу.

Сва мерења су обављена у лабораторијским условима. Телесна висина измерена је висинометром Seca (Germany), док су маса тела и проценат масног ткива измерени специјализованом вагом за процену телесне композиције Танита бц-418ма (Japan). Уз помоћ динамометра Globus ergo tesys system 1000, Real power (Italy), динамометријском методом измерена је максимална изометријска мишићна сила и време њеног достизања у тесту получучањ.

\section{Статистичка обрада података}

Применом одговарајућег оперативног статистичког програма (СПСС), за све варијабле изарачуната је аритметичка средина и стандардна девијација. Како би утврдили да ли се групе међусобом разликују на иницијалном мерењу кориштена je Post hoc анализа (Takey-ev HSD критеријум). Применом Т-теста за зависне узорке, тестирана је разлика резултата на иницијалном и финалном мерењу за сваку групу. Ниво значајности је постављен на $\mathrm{p}=0,05$.

\section{РЕЗУЛТАТИ}

У табели 1 приказане су средње вредности и стандардне девијације морфолошких карактеристика кошаркаша јуниора. Вредности телесне висине, телесне масе и процента масног ткива су приближно једнаке у експерименталној и контролној групи на иницијалном и финалном мерењу.

Табела 1 Основни статистички показатељи морфолошких карактеристика узорка на иницијалном и финалном мерењу

\begin{tabular}{|c|c|c|c|c|}
\hline \multirow{3}{*}{ Варијабле } & \multicolumn{4}{|c|}{ Иницијално мерење } \\
\hline & \multicolumn{2}{|c|}{$\begin{array}{c}\text { Експериментална група } \\
(\mathrm{N}=10)\end{array}$} & \multicolumn{2}{|c|}{$\begin{array}{c}\text { Контролна група } \\
(\mathrm{N}=10)\end{array}$} \\
\hline & $\mathrm{AC}$ & СД & AC & СД \\
\hline $\mathrm{TB}(\mathrm{cm})$ & 186.00 & 4.34 & 186.40 & 4.19 \\
\hline $\mathrm{TM}(\mathrm{kg})$ & 75.00 & 4.57 & 75.80 & 3.08 \\
\hline MT (\%) & 12.81 & 1.43 & 12.86 & 0.91 \\
\hline \multirow{3}{*}{ Варијабле } & \multicolumn{4}{|c|}{ Финално мерење } \\
\hline & \multicolumn{2}{|c|}{ Експериментална група } & \multicolumn{2}{|c|}{ Контролна група } \\
\hline & AC & СД & AC & СД \\
\hline $\mathrm{TB}(\mathrm{cm})$ & 186.40 & 4.22 & 186.80 & 4.21 \\
\hline $\mathrm{TM}(\mathrm{kg})$ & 75.30 & 4.78 & 76.15 & 2.71 \\
\hline MT (\%) & 12.56 & 1.23 & 12.81 & 0.74 \\
\hline
\end{tabular}


Кукрић А., и сар., Утицај комплексног метода тренинга..., ФИЗИЧКА КУЛТУРА 2019; 73 (2): 261-270

У табели 2 приказане су средње вредности и стандардне девијације максималне изометријске мишићне силе, времена њеног достизања и индекса експлозивне снаге у тесту получучањ на иницијалном и финалном мерењу.

Табела 2 Статистички показатељи максималне изометријске мишићне силе, време њеног достизања и индекс експлозивне снаге у тесту получучањ на иницијалном и финалном мерењу

\begin{tabular}{|c|c|c|c|c|c|c|c|c|}
\hline \multirow{3}{*}{ Варијабле } & \multicolumn{4}{|c|}{ Иницијално мерење } & \multicolumn{4}{|c|}{ Финално мерење } \\
\hline & \multicolumn{2}{|c|}{ Екс. група } & \multicolumn{2}{|c|}{ Кон. група } & \multicolumn{2}{|c|}{ Екс. група } & \multicolumn{2}{|c|}{ Кон. група } \\
\hline & AC & СД & $\mathrm{AC}$ & СД & AC & СД & AC & СД \\
\hline МИС (N) & 1442.21 & 198.49 & 1441.01 & 149.31 & 1647.32 & 174.06 & 1461.51 & 145.97 \\
\hline ВМИС (s) & 1.47 & 0.25 & 1.45 & 0.16 & 1.43 & 0.22 & 1.44 & 0.16 \\
\hline ИЕС (N/s) & 981.09 & 220.41 & 993.80 & 162.40 & 1151.97 & 185.47 & 1014.93 & 155.31 \\
\hline
\end{tabular}

У табели 3 приказани су резултати анализе варијансе на иницијалном мерењу. Нису забележене статистички значајне разлике у тестираним варијаблама између експерименталне и контролне групе на иницијалном мерењу. Тиме је задовољен један од основних методолошких захтева истраживања са паралелним групама, по коме је неопходно да на почетку експеримента, између група не постоји статистички значајна разлика у тестираним варијаблама.

Табела 3 Резултати анализе варијансе експерименталне и контролне групе на иницијалном мерењу

\begin{tabular}{lcc}
\hline Варијабле & F-test & Sig. \\
\hline МИС (N) & .39 & .68 \\
ВМИС (s) & .11 & .89 \\
ИЕС (N/s) & .99 & .38 \\
\hline
\end{tabular}

У табели 4 приказани су резултати t-теста за зависне узорке. Тестирана је значајност разлика између просечних вредности варијабли експерименталне и контролне групе на иницијалном и финалном мерењу. Резултати мерења указују да у експерименталној групи постоји статистички значајна разлика у варијаблама МИС и ИЕС, док у варијабли ВМИС нису забележене статистички значајне разлике. У контролној групи нису забележене статистички значајне разлике ни у једној тестираној вријабли.

Табела 4 Значајност разлика између средњих вредности варијабли експерименталне и контролне групе на иницијалном и финалном мерењу

\begin{tabular}{lcccc}
\hline \multirow{2}{*}{ Варијабле } & \multicolumn{2}{c}{ Екс. група } & \multicolumn{2}{c}{ Кон. група } \\
\cline { 2 - 5 } & $\mathbf{t}$ & Sig. & $\mathbf{t}$ & Sig. \\
\hline МИС (N) & $-16.59^{\star}$ & $.00^{\star}$ & -1.76 & .11 \\
ВМИС (s) & 1.33 & .21 & .10 & .91 \\
ИЕС (N/s) & $-6.89^{*}$ & $.00^{*}$ & -.59 & .56 \\
\hline
\end{tabular}

* статистички значајна разлика

У сликама 1, 2 и 3 приказане су значајност разлика аретметичких средина тестираних варијабли испитаника експерименталне и контролне групе на иницијалном и финалном мерењу у тесту получучањ. 


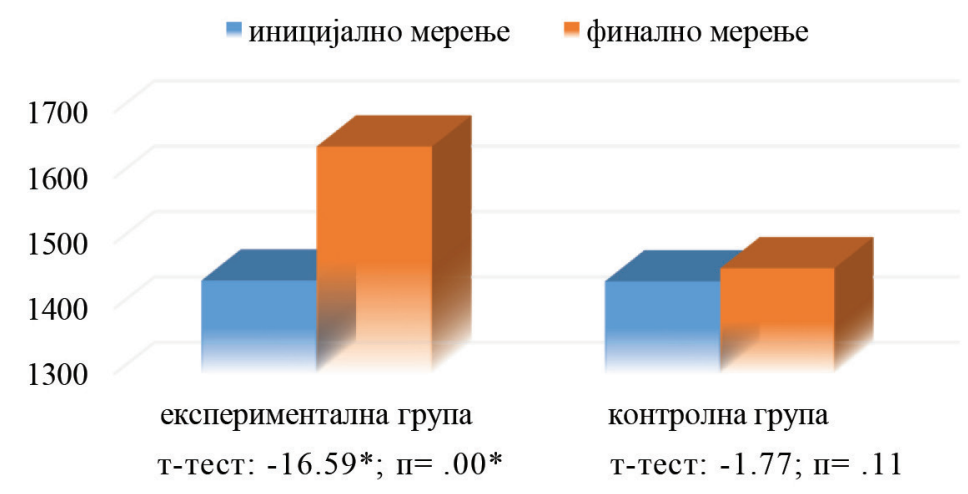

Слика 1 Значајност разлика аритметичких средина максималне изометријске мишићне силе (N) испитаника експерименталне и контролне групе на иницијалном и финалном мерењу

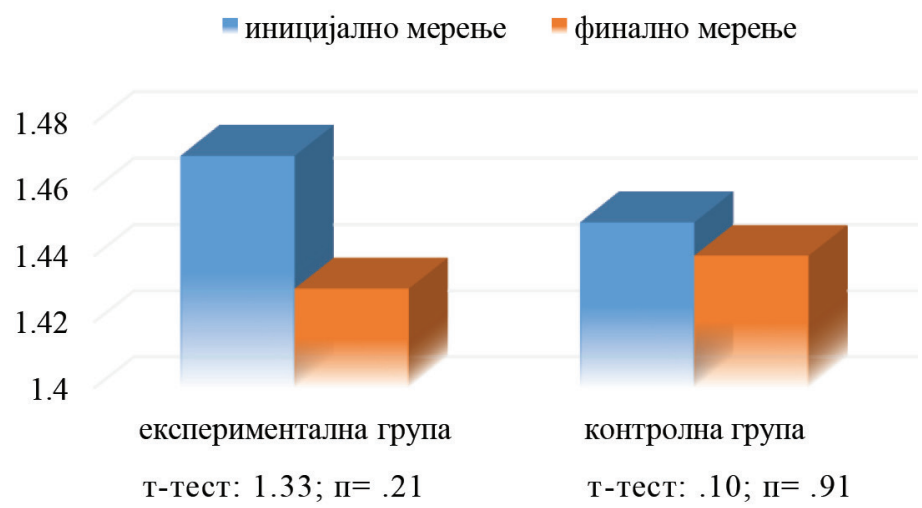

Слика 2 Значајност разлика аритметичких средина времена достизања максималне изометријске мишићне силе (s) испитаника експерименталне и контролне групе на иницијалном и финалном мерењу

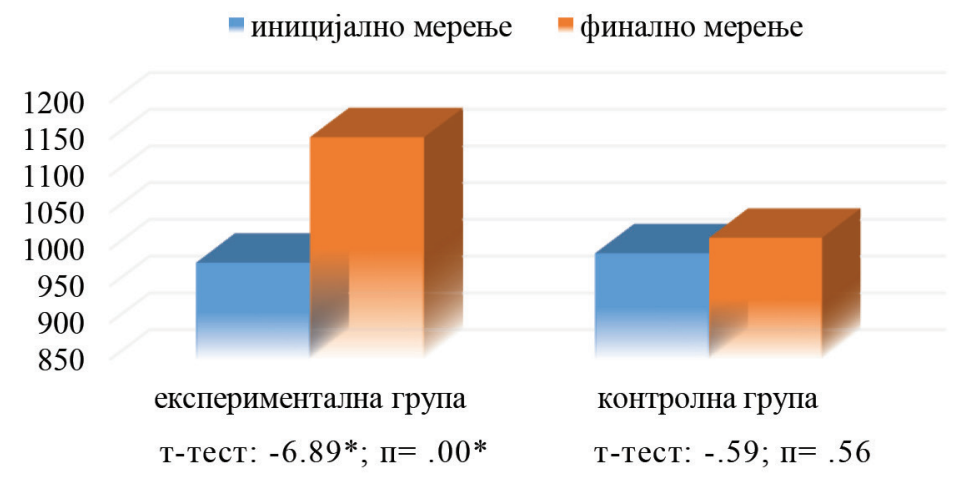

Слика 3 Значајност разлика аритметичких индекса експлозивне снаге (N/s) испитаника експерименталне и контролне групе на иницијалном и финалном мерењу. 
Кукрић А., и сар., Утицај комплексног метода тренинга..., ФИЗИЧКА КУЛТУРА 2019; 73 (2): 261-270

\section{ДИСКУСИЈА}

Вредности измерених морфолошких карактеристика указују да се ради о испитаницима одговарајућег односа телесне висине и масе тела, са релативно малим уделом масног ткива у телесној композицији (Табела 1). На финалном мерању нису забележене значајније промене у праћеним морфолошким атрибутима испитаника. Целокупан програм вежбања није оставио значајније ефекте на телесну масу и проценат масног ткива. Када је у питању телесна висина, нису ни очекиване значајније промене у кратом временском периоду трајања експерименталног програма. Будући да се испитивао утицај комплексног метода тренинга, чија је основа извођење експлозивних и брзих покрета, сасвим је јасно зашто није дошло до активирања метаболичких процеса чиме би се значајније утицало на проценат масног ткива и телесну масу.

Измерене вредности максималне изометријске мишићне силе, време њеног достизања и индекса експлозивне снаге на иницијалном мерењу указују да испитаници имају приближно сличне способности у испољавању изометријског напрезања у тесту получучањ (Табела 2). Резултати анализе варијансе на иницијалном мерењу указију на изостајање значајнијих разлика између група узорка, што је омогућило започињање експерименталног програма (Табела 3 ).

Резултати финалног мерења изометријског напрезања у тесту получучањ, указују да су ce након десетонедељног програма вежбања догодиле одређене промене у погледу испољавања максималне изометријске мишићне силе (Табела 4, слике 1, 2 и 3). На финалном мерењу утврђене су статистички значајне разлике у варијабли МИС и ИЕС у експерименталној групи. Праћењем промена параметара у тесту получучањ, установљено је повећање максималне изометријске силе за $14.22 \%$, као и побољшање индекса експлозивне снаге за $17.41 \%$ у односу на иницијално мерење. Иако се нису догодиле значајније промене у времену достизања максималне изометријске мишићне силе, побољшање индекса експлозивне снаге резултат је значајнијег повећања максималне изометријске мишићне силе. У контролној групи нису регистроване значајније промене у тестираним варијаблама. Изостајање значајних промена у варијаблама контролне групе су савим очекиване, будући да испитници нису учествовали у програму тренинга за развој силе и снаге, тако да се нису могле очекивати значајније промене на кривој сила-брзина. Како у контролној групи није дошло до значајнијих промена, сва настала побољшања у експерименталној групи, са великим нивоом вероватноће, могу се приписати примени експерименталног десетонедељног програма вежбања.

Значајно веће вредности максималне изометријске мишићне силе у тесту получучањ указују да вежбе динамичког карактера имају позитиван ефекат на изометријско напрезање. Иако је била очекивана промена и у брзини мишићне контракције, с обзиром да је програм вежбања подразумевао извођење експлозивних покрета у режиму ексцентрично-концентричне контракције, та промена је овог пута изостала. Нека од истраживања су потврдила да тренинг са оптерећењем може да утиче на брзину развоја мишићне силе у изометријским условима. У једном од истраживања дошло се до закључка да тренинг са оптерећењем може да повећа фреквенцију пражњења нервних импулса, као и да то повећање може да проузрокује већу брзину развоја мишићне силе (Sale, 2003). Као један од могућих разлога због чега није дошло до промена у времену испољавања максималне изометријске мишићне силе, може се навести релативно кратка пауза између вежбе потенцијације и експлозивне вежбе. Као што је познато, ефекти извођења брзинско - експлозивних вежби су највећи у условима потпуног опоравка мишића. Могуће је да је двоминутна пауза била недовољна за потпуни опоравак, посебно опоравак неуралне компонете мишићне активности, од које у великој мери зависи брзина испољавања мишићне силе. Зајц и сарадници (Seitz et al., 2014) су у свом истраживању дошли до закључка да су код тренираних спортиста најизраженији ефекти ПАП након 6 минута паузе између вежби у комплексу, док код слабије тренираних пауза је била чак 9 минута. Како су забележене само значајније промене у изометријској сили, може се закључити да су ефекти комплексног тренинга превасходно усмерени на мишићну адаптацију, те да сусе промене вероватно догодиле као последица промене физиолошког пресека мишића. 
Постоје две компоненте које одређују испољавање максималне мишићне силе. Неурална компонента се односи на активност централног нервног система (ЦНС), који на више начина утиче на мишићну активност. Са аспекта утицаја ЦНС, максимална мишићна сила може да се развије: регрутовањемшто већег броја моторних јединица, оптималном фреквенцијом пражњења нервних импулса у циљу стварања тетанусне контракције и истовременим деловањем моторних јединица у кратком временском периоду током максимлане вољне контракције (Sale, 2003). Мишићна компонента се односи на утицај структуре и архитектуре мишића на масималну мишићну силу. Максимална мишићна сила се може повећати на рачун повећања физиолошког пресека мишића (Luthi et al, 1986; Young, Stokes, \& Round, 1983; Folland, \& Wiliams, 2007; Fitts, \& Widrick, 1996), која може настати као резултат два физолошка механизма, хипертрофије и хиперплазије. Највеће промене у мишићној архитектури резултат је пре хипертрофије, него хиперплазије. Хакинен и сарадници (Häkkukinen, Komi, \& Alén, 1985) су у периоду од 24 недеље испитивали утицај тренинга експлозивне снаге на изометријску силу мишића екстензора ногу. Електромиографским мерењем анализирали су криву сила-брзина и установили статистички значајно побољшање у максималној изометријској сили мишића екстензора ногу, као и побољшање брзине генерисања изометријске мишићне силе. Као један од узрока ових побољшања, аутори наводе повећање физолошког пресека мишића, поготово у условима извођења плиометријских вежби у комбинацији са додатним спољашњим оптерећењем. Слични резултати су добијени у истраживању које је организовано у периоду од 12 недеља, где су се биопсијом мишића пратиле промене у попречном пресеку $\mathrm{m}$. bicep brachi. Установљено је повећање попречног пресека брзих влакана за 17\% и спорих влакана за 10\% (McCall et al,1996).

\section{ЗАКЉУЧАК}

Последње деценије се све више истражују ефекти комплексног тренинга, који представља поуздан метод у припреми спортиста, те га многи тренери препоручују као ефикасан метод рада у тренажном процесу. Посебан значај овог истраживања огледа се у испитивању ефеката комплексног тренинга на параметре силе и времена при изометријском мишићном напрезању. Резултати истраживања су потврдили ефикасност комплексног метода тренига на испољавање максималне изометријске мишићне силе. Остварени су статистички значајно бољи резултати у групи која је тренирала комплексним методом тренинга у односу на контролну групу. Примена експериментаног програма није донела значајније промене времена остварења максималне изомеријске силе. Очигледно је да су се под утицајем експерименталног програма догодиле само адаптације мишићног ткива на тренинг силе и снаге, што је довело до значајнијих побољшања у испољавању максималне мишићне силе у условима изометријског напрезања.

\section{ЛИТЕРАТУРА}

1. Bazyler, C.D., Beckham, G.K., Sato, K. (2015). The Use of the Isometric Squat as a Measure of Strength and Explosiveness, Journal of Strength \& Conditioning Research, 29(5), 1386-1392.

2. Behrens, M., Mau Moeller, A., Mueller, K., Sandra Heise, S., Gube, M., Beuster, N., Herlyn, P.K.E., Fischer, D.C., \& Bruhn, S. (2016). Plyometric training improves voluntary activation and strength during isometric, concentric and eccentric contractions. Journal of Science and Medicine in Sport, 19(2), 170-176.
3. Brzycki, M. (1993). Strength testing: Predicting a onerep max from reps to fatigue. Journal of Physical Education, Recreation and Dance, 64, 88-90.

4. Burger, T., Boyer-Kendrick, T., \& Dolny, D. (2000). Complex training compared to a combined weight training and plyometric training program. Journal of Strength \& Conditioning Research, 14(3), 360-361

5. Chiu, L. Z., Fry, A. C., Weiss, L. W., Schilling, B. K., Brown, L. E., \& Smith, S. L. (2003). Postactivation Potentiation Response in Athletic and Recreationally 
Trained Individuals. Journal of Strength and Conditioning Research, 17(4), 671-677.

6. Clutch, D., Wilton, M., McGown, C., \& Bryce, G.R. (2013). The Effect of Depth Jumps and Weight Training on Leg Strength and Vertical Jump. Research Quarterly for Exercise and Sport, 54(1), 5-10.

7. Comyns, T.M., Harrison, A.J., \& Hennessy, L.K. (2010). Effect of squatting on sprinting performance and repeated exposure to complex training in male rugby players. Journal of Strength \& Conditioning Research, 24, 610-618.

8. Comyns, T.M., Harrison, A.J., Hennessy, L.K., \& Jensen, R.L. (2006). The optimal complex training rest interval for athletes from anaerobic sports. Journal of Strength \& Conditioning Research, 20, 471-476.

9. Duthie, G. M., Young, W. B., \& Aitken, D. A. (2002). The acute effects of heavy loads on jump squat performance an evaluation of the complex and contrast methods of power development. Journal of Strength and Conditioning Research, 16(4), 530-538.

10. Ebben, W.P., \& Blackard, D.O. (1997). Complex training with combined explosive weight training and plyometric exercises. Olympic Coach, 7, 11-12.

11. Ebben, W.P., Jensen, R.L., Blackard, D.O. (2000). EMG and kinetic analysis of complex training exercise variables. Journal of Strength \& Conditioning Research, 14: 451-456.

12. Fitts, R.H., \& Widrick, J.J. (1996). Muscle mechanics: adaptations with exercise-training. Exercise and Sport Sciences Reviews, 24, 427-473.

13. Folland, J.P., \& Williams, A.G. (2007). The adaptations to strength training: morphological and neurological contributions to increased strength. Sports Medicine, 37(2), 145-68.

14. French, D., Kramer, W.J., Cooke, C.B. (2003). Changes in Dynamic Exercise Performance Following a Sequence of Preconditioning Isometric Muscle Actions. Journal of Strength \& Conditioning Research, 17(4), 678-685.

15. Gossen, E.R., \& Sale, D.G. (2000). Effect of postactivation potentiation on dynamic knee extension performance. European Journal of Applied Physiology, 83(6), 524-530.

16. Gourgoulis, V., Aggeloussis, N., Kasimatis, P., Mavromatis, G., \& Garas, A. (2003). Effect of a submaximal half-squats warm-up program on vertical jumping ability. Journal of Strength and Conditioning Research, 17(2) 342-344.
17. Häkkukinen, K., Komi, P.V. \& Alén, M. (1985). Effect of explosive type strength training on isometric force and relaxation time, electromyographic and muscle fibre characteristics of leg extensor muscles. Acta Physiologica Scandinavica, 125, 587-600.

18. Hodgson, M.J., Docherty, D., Zehr E.Z. (2008). Postactivation Potentiation of Force Is Independent of H-Reflex Excitability. International Journal of Sports Physiology and Performance, 3(2), 219-231.

19. Jensen, R.L., \& Ebben, W.P. (2003). Kinetic analysis of complex training rest interval effect on vertical jump performance. Journal of Strength \& Conditioning Research, 17(2), 345-9.

20. Jensen, R.L., Ebben, W.P., Blackard, D.O., Mclaughlin, B.P., \& Watts, P.B. (1999). Kinetic and electromyographic analysis of combined strength and plyometric training in women basketball players. Medicine \& Science in Sport \& Exercise, 31(5), 193.

21. Кукрић, А., Каралејић, М., Петровић, Б., Јаковљевић, S. (2009). Утицај комплексног тренинга на експлозивну снагу опружача ногу код кошаркаша јуниора. Физичка култура, 63(2), 165-180.

22. Luthi, J.M., Howald, H., Cbsen, H., Rosler, K., \& Vodc, P.H. (1986). Structural changes in skeletal muscle tissue with heavy resistance exercise. International Journal of Sports \& Medicine, 7(3), 123-127.

23. McCall, G. E., Byrnes, W. C., Dickinson, A., Pattany, P. M., \& Fleck, S. J. (1996). Muscle fiber hypertrophy, hyperplasia, and capillary density in college men after resistance training. Journal of Applied Physiology, 81(5), 2004-2012.

24. Requena, B., Gapeyeva, H., García, I., Ereline, J., Paasuke, M. (2008). Twitch potentiation after voluntary versus electrically induced isometric contractions in human knee extensor muscles. Euro Journal of Applied Physiology, 104(3), 463-472.

25. Rixon, K.P., Lamont, H.S., Bemben, M.G. (2007). Influence of type of muscle contraction, gender, and lifting experience on postactivation potentiation performance. Journal of Strength \& Conditioning Research, 21(2), 500-505.

26. Robbins, D.W. (2005). Postactivation potentiation and its practical applicability: a brief review. Journal of Strength \& Conditioning Research, 19(2), 453-458.

27. Roden, D., Lambson, R., DeBeliso, M. (2014). The Effects of a Complex Training Protocol on Vertical Jump Performance in Male High School Basketball Players. Journal of Sports Science, 2, 21-26. 
28. Sale, D. G. (2003). Neural adaptations to strength training. In: Komi PV, editor. Strength and Power in Sport. 2nd ed. Malden (MA), Blackwell Science, 281-314.

29. Seitz, L.B., de Villarreal, E.S., \& Haff, G.G. (2014). The temporal profile of postactivation potentiation is related to strength level. Journal of Strength \& Conditioning Research, 28(3), 706-715.

30. Siff, M. C. \& Verkhoshansky, Y. V. (1999). Supertraining. Denver: Supertraining International.

31. Tsolakis, C., Bogdanis, G., Nikolaou, A., Zacharogiannis, E. (2011). Influence of type on muscle contraction and gender on postactivation potentiation of upper and lower explosive performance in elite fencers. Journal of Sports Science and Medicine, 10, 577-583.

32. Weber, K.R., Brown, L.E., Coburn, J.W., \& Zinder, S.M. (2008). Acute effects of heavy load squats on consecutive squat jump performance. Journal of Strength \& Conditioning Research, 22(3), 726-30.
33. Wilson, J.M., Duncan, N.M., Marin, P.J., Brown, L.E., Loenneke, J.P., Wilson, S.M., Jo, E., Lowery, R.P., \& Ugrinowitsch, C. (2013). Meta-analysis of postactivation potentiation and power: effects of conditioning activity, volume, gender, rest periods, and training status. Journal of Strength \& Conditioning Research, 27(3), 854-9.

34. Xenofondos, A., Laparidis, K., Kyranoudis, A., Galazoulas, Ch., Bassa, E., \& Kotzamanidis, C. (2010). Postactivation potentiation: factors affecting it and the effect on performance. Journal of Physical Education and Sport, 28(3), 32-38.

35. Young, A., Stokes, M., \& Round, J.M. (1983). The effect of high ristance training on the strength and cross sectional area of the human quadriceps. European Journal of Clinical Investigation, 13(5), 411-417.

36. Young, W. B., Jenner, A., \& Griffiths, K. (1998). Acute enhancement of power performance from heavy load squats. Journal of Strength \& Conditioning Research, 12(2), 82-84.

Примљен: 06.9.2018.

Прихваћен: 14.1.2019.

Online објављен: 13.4.2019. 